\section{Assessment of Ramifications in the Apical Region of Root Canals: A Micro- CT Study in a Brazilian Population}

\author{
Natalia Siqueira Lobo ${ }^{10}$, Victor Aquino Wanderley ${ }^{(0)}$, Yuri Nejaim ${ }^{2}$,
} Amanda Farias Gomes ${ }^{2}$, Alexandre Augusto Zaia ${ }^{1}$ (D)

\author{
'Department of Restorative Dentistry, \\ Endodontic Division, Piracicaba Dental \\ School, State University of Campinas, \\ Piracicaba, São Paulo, Brazil \\ ${ }^{2}$ Department of Oral Diagnosis, \\ Division of Oral Radiology, \\ Piracicaba Dental School, \\ State University of Campinas, \\ Piracicaba, São Paulo, Brazil
}

Correspondence: Natalia Siqueira Lobo, Avenida Limeira, 901, 13414-903 Piracicaba, SP, Brasil. Tel: +55-19-2106-5200. e-mail: nasiqueiralobo@gmail.com

\begin{abstract}
The present study used microcomputed tomography (micro-CT) images to assess the prevalence, number, and location of apical ramifications (ARs) in the root canals of different dental groups in a Brazilian population. Three hundred and sixty-seven extracted human teeth, totaling 475 roots, were scanned by micro-CT at $19.6 \mu \mathrm{m}$ spatial resolution. The obtained images were evaluated by two observers in consensus, and a descriptive analysis was performed to verify the prevalence, number, and location of ARs in each dental group. Chi-square test was used to compare the prevalence of ARs in different types of roots, and one-way analysis of variance compared the number of ARs in the apical $1 \mathrm{~mm}, 2 \mathrm{~mm}$, and $3 \mathrm{~mm}$ of the root. Significance level was established at $5 \%(\alpha=0.05)$. ARs were present in $253(53.3 \%)$ of the 475 roots evaluated. A total of 607 ARs were detected, with the vast majority (530) located at one and two millimeters from the main foramen. The highest prevalence of ARs was observed in maxillary canines (65\%); maxillary premolars - single-rooted (83.3\%), buccal root (80\%), and palatine root (73.3\%); mandibular premolars (64.2\%); mesiobuccal root of maxillary molars (76.6\%); and mesial root of mandibular molars $(66.6 \%)$. For the Brazilian population, most of the ARs are located in the apical 1 and $2 \mathrm{~mm}$ of the root, with greater prevalence in the posterior teeth and maxillary canines. These findings suggest the need for additional attention while planning endodontic treatments, including strategies to effectively clean and fill the apical region.
\end{abstract}

Key Word: endodontics, dental pulp cavity, x-ray microtomography, tooth apex.

\section{Introduction}

Knowledge about the anatomical complexities of the root canals is highly associated with a successful endodontic therapy, due to the influence of such complexities on diagnosis, planning and clinical conduct $(1,2)$. Anatomical irregularities may be seen along the entire root length; however, the apical third is more likely to have several ramifications of the main canal. The prevalence of apical ramifications (ARs) in human permanent teeth varies among populations and according to the methodology used to assess them. Thus, previous studies reported that the prevalence of ARs ranged from $17.1 \%$ to $75 \%$ (3-5).

When in the presence of bacterial contamination, ARs represent a risk factor for the long-term prognosis of endodontic therapy. ARs connect the main canal to the periodontal ligament and, as they are unlikely to be cleaned with conventional instrumentation and irrigation, biofilms may grow and cause periapical diseases $(5,6)$. Hence, knowledge about the prevalence of irregularities in the apical region of different groups of teeth may guide the need for more specific procedures such as correct determination of the working length, agitation of irrigating solutions, and filling of ARs using an adequate obturation technique, in order to prevent an inflammatory response or treatment failure $(7,8)$

Considering the impact of root canal anatomy on endodontic therapy, several studies using different evaluation methods, such as histology, clearing technique, scanning electron microscopy, cone beam computed tomography and microcomputed tomography (micro-CT), have been performed $(4,9,10)$. Micro-CT has been widely used for the analysis of root canal systems due to its nondestructive nature, three-dimensionality, and high spatial resolution, which allows to evaluate subtle aspects of root canal anatomy $(11,12)$.

In-depth knowledge about the anatomy of the root canals and its possible variations is essential for endodontists to plan and accomplish a successful endodontic treatment (2). The Brazilian population show great ethnic and racial diversity and, to date, there are no micro-CT studies on the characterization of ARs in different dental groups of this population, using a large sample size. Therefore, the aim in this study was to assess the prevalence, number, and location of apical ramifications in the root canals of different dental groups of a Brazilian population, using micro-CT images. 


\section{Material and Methods}

The present study was designed according to the local institutional review board and was performed after its approval (CAAE 67465617.8.0000.5418).

\section{Data Collection}

The study sample was composed of 367 extracted human teeth: 42 mandibular incisors, 58 maxillary incisors, 47 mandibular canines, 35 maxillary canines, 53 mandibular premolars, 69 maxillary premolars, 33 mandibular molars and 30 maxillary molars. Along with tri- and bi-rooted molars, some maxillary premolars had two roots, totaling 475 dental roots in the final sample. Exclusion criteria consisted of teeth with open apex, root canal dilaceration, pulp calcifications, root fractures or cracks, root resorptive lesions, and root canal treatment. These conditions were diagnosed through clinical and radiographic examination. Patient's age and sex were unknown, and the cause of extraction was unrelated to this study.

All teeth were disinfected with a $2 \%$ chlorhexidine solution for $30 \mathrm{~min}$, rinsed thoroughly with distilled water, and then calculus and remaining soft tissues were removed by ultrasonic scaling. Before scanning, the sample was kept hydrated in distilled water at room temperature for one month. Micro-CT images were obtained using a SkyScan 1174 device (Bruker, Kontich, Belgium), operating at $50 \mathrm{kV}$ and $800 \mu \mathrm{A}$, with a $0.5 \mathrm{~mm}$ aluminum filter, $360^{\circ}$ rotation, $0.5^{\circ}$ rotation step and isotropic voxel size of $19.6 \mu \mathrm{m}$. The scanning was performed with the X-ray beam directed perpendicular to the longitudinal axis of the teeth.

\section{Image Assessment}

The scanning data set of the teeth was imported into the NRecon software (Bruker, Kontich, Belgium) for reconstruction. Then, using the DataViewer software (Bruker, Kontich, Belgium), each dental root, especially of the multi-rooted teeth, was adjusted so that the root axis was parallel to the sagittal plane. The apical limit was established at the level of the main foramen to standardize

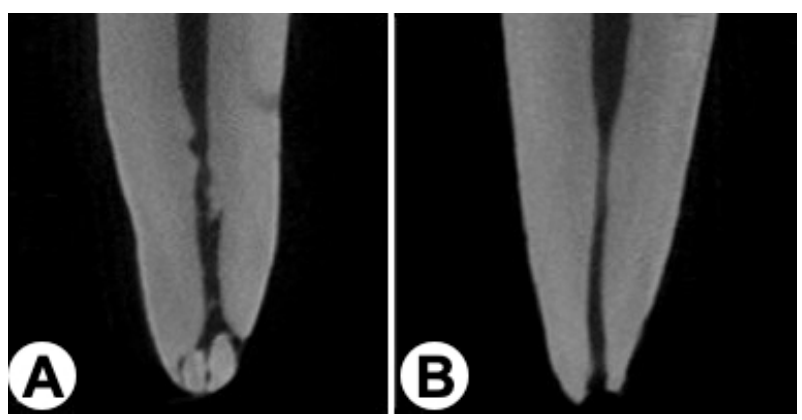

Figure 1. Coronal reconstructions of micro-CT showing presence (A) and absence (B) of ramifications in the apical region of the roots. the sample and determine the apical $3 \mathrm{~mm}$ of the root. A new data set of the cross sections of the apical segment was exported in TIFF format for evaluation. All obtained images were evaluated by consensus by an oral radiologist and an endodontist regarding the presence, number, and location of ARs. The examiners were instructed to consider the presence of ARs as any branch from the main pulp canal that communicates with the outer surface of the root (2) (Fig. 1).

Images were evaluated in a 24.1-in. LCD monitor (MDRC-2124, Barco N.V., Courtray, Belgium) with 1920 x 1200 pixels resolution, in a silent and dimmed-light room. The examiners were allowed to manipulate image brightness, contrast, and zoom as they pleased. All data was recorded in a Microsoft Office Excel (Microsoft, Redmond, WA, USA) spreadsheet and submitted to statistical analysis. One month after completion of the evaluations, 20\% of the sample was re-evaluated to test intraexaminer reproducibility.

\section{Statistical Analysis}

The sample size was calculated based on the estimated population proportion using the following formula:

$$
n=\frac{\left(z_{\alpha / 2}\right)^{2} \cdot p \cdot q}{E^{2}}
$$

where, " $n$ " is the number of individuals in the sample; "Z $\alpha / 2$ " is the critical value that corresponds to the desired level of confidence - in the present study, the confidence level was set at $95 \%(\alpha=0.05)$, thus the critical value is 1.96; " $p$ " is the population proportion that belong to the studied category, and " $q$ " is the population proportion that does not belong to the studied category - since these proportions were not known, the value of 0.5 was selected for both " $p$ " and " $q$ "; and " $E$ " is the margin of error (0.05). As a result of this equation, the sample size of approximately 384 individuals was obtained. Based on this calculation, 475 dental roots were selected to compose a larger study sample. Additionally, the sample power calculation was 0.9969. The Kolgomorov-Smirnov test verified the normality of the sample distribution. Descriptive analysis was performed to assess the prevalence and number of ARs in each dental group. Chi-square test compared the prevalence of ARs in the different types of roots, and one-way ANOVA compared the number of ARs in the apical $1 \mathrm{~mm}, 2 \mathrm{~mm}$, and $3 \mathrm{~mm}$ of the root. Intraclass correlation coefficient (ICC) test evaluated the intraexaminer agreement. Significance level was established at 5\% for all analyses ( $\alpha=0.05)$.

\section{Results}

ARs were present in $253(53.3 \%)$ of the 475 roots 
evaluated. The highest percentage of ARs was observed in single-rooted maxillary premolars (83.3\%); however, no statistically significant difference was observed among this group and the maxillary canines, bi-rooted maxillary premolars, mandibular premolars, mesiobuccal roots of maxillary molars, and mesial root of mandibular molars $(p>0.05)$. The lowest percentage of root canal ramifications was found in the maxillary incisors (17.2\%), although it did not differ statistically from the mandibular incisors and mandibular canines ( $p>0.05$ ) (Table 1).

Figure 2 shows micro-CT segmented images of $A R$ in each dental group. Of the 253 roots with ARs, 109 roots had only 1 AR each; 64 roots had 2 ARs each; and 80 roots had 3 or more ARs each. The number of ARs ranged from 1 to 17 for each dental root. As shown in Table 2, a total of 607 ARs were detected, with the vast majority (530) located at one and two millimeters from the main foramen. The number of ARs was significantly greater $(p<0.05)$ at $1 \mathrm{~mm}$ and $2 \mathrm{~mm}$ than at $3 \mathrm{~mm}$ from the main foramen, and it did not differ significantly ( $p>0.05)$ between the distances of $1 \mathrm{~mm}$ and $2 \mathrm{~mm}$ from the main foramen.

The intraclass correlation coefficient showed an excellent intraexaminer agreement (0.97).

\section{Discussion}

In the present study, 475 dental roots from a Brazilian

Table 1. Prevalence of apical ramifications (ARs) in the apical $3 \mathrm{~mm}$ of the root for different dental groups

\begin{tabular}{lccc}
\hline Dental group & $\begin{array}{c}\text { Roots } \\
(\mathrm{n})\end{array}$ & $\begin{array}{c}\text { Presence of ARs } \\
(1-3 \mathrm{~mm})(\%)\end{array}$ & $\begin{array}{c}\text { Absence of ARs } \\
(1-3 \mathrm{~mm})(\%)\end{array}$ \\
\hline Maxillary & & & \\
Incisor & 58 & $10(17.2 \%)$ & $48(82.8 \%)$ \\
Canine & 35 & $23(65.7 \%)$ & $12(34.3 \%)$ \\
Premolar & & & \\
Premolar single-rooted & 54 & $45(83.3 \%)$ & $9(16.7 \%)$ \\
Premolar buccal root & 15 & $12(80 \%)$ & $3(20 \%)$ \\
Premolar palatine root & 15 & $11(73.3 \%)$ & $4(26.7 \%)$ \\
Molar & & & \\
Molar mesiobuccal root & 30 & $23(76.6 \%)$ & $7(23.4 \%)$ \\
Molar distobuccal root & 30 & $13(43.3 \%)$ & $17(56.7 \%)$ \\
Molar palatine root & 30 & $13(43.3 \%)$ & $17(56.7 \%)$ \\
Mandibular & & & \\
Incisor & 42 & $12(28.5 \%)$ & $30(71.5 \%)$ \\
Canine & 47 & $16(34 \%)$ & $31(66 \%)$ \\
Premolar & 53 & $34(64.2 \%)$ & $19(35.8 \%)$ \\
Molar & & & $11(33.4 \%)$ \\
Molar mesial root & 33 & $22(66.6 \%)$ & $222(46.7 \%)$ \\
Molar distal root & 33 & $19(57.5 \%)$ & $14(42.5 \%)$ \\
Total & 475 & $253(53.3 \%)$ & \\
\hline
\end{tabular}

population were assessed for the prevalence, number, and location of ARs, using micro-CT images. The general prevalence of ARs was 53.3\%, and a total of 607 ARs were detected; these ARs were considered as any branch from the main canal terminating at the root surface, including accessory and secondary canals, and apical deltas.

In clinical practice, some endodontists establish the working length for endodontic procedures at the level of the main foramen, arguing that residual pulp tissue can become infected and potentially develop periradicular diseases $(13,14)$. Through histopathological examination of tissues resected from roots with persistent periapical periodontitis, extensive bacterial biofilms and inflammatory tissues were observed in the ramifications (15). These ramifications are unlikely to be thoroughly debrided by conventional instrumentation and irrigation techniques (16); thus, effective methods for cleaning and disinfecting AR are still needed and require further investigation. Yet, the philosophy of some other endodontists is to define the working length at the apical constriction of the root ( 0.5 to $2 \mathrm{~mm}$ shorter than the radiographic root apex) $(17,18)$, which leaves the apical region of the main canal untouched. Consequently, no chemomechanical preparation reaches the ARs space. According to previous studies, ARs are predominantly located at the apical region in all dental groups $(3,4)$. In the present study, it was observed that most ARs were located at $1 \mathrm{~mm}$ and $2 \mathrm{~mm}$ from the main foramen. Therefore, our results reinforce that, in the presence of pulp necrosis, it would be reasonable to shape and clean the root canal space along its entire length, combining irrigation strategies to obtain the best effects in ARs disinfection (8).

The prevalence of root canal ramifications may vary according to the dental group, root region, populations, and method of analysis (19). Micro-CT has achieved increasing significance in the study of root canal anatomy, due to its high image quality and nondestructive nature

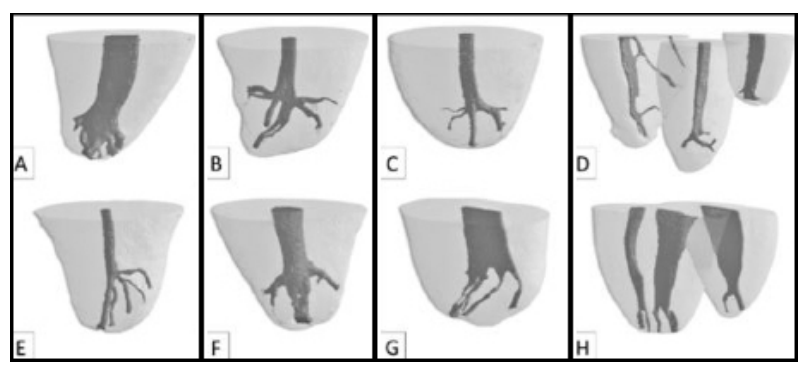

Figure 2. Three-dimensional images of micro-CT showing root canal ramifications (1 to $3 \mathrm{~mm}$ from the apex). (A) Maxillary incisor, (B) Maxillary canine, (C) Maxillary premolar, (D) Maxillary molar, (E) Mandibular incisor, (F) Mandibular canine, (G) Mandibular premolar, and $(\mathrm{H})$ Mandibular molar. 
(12). The study of complex structures using CBCT and clearing technique has shown poor results compared to micro-CT, which overcomes several limitations of these methods and is superior in identifying fine anatomical details $(20,21)$. The excellent ICC results $(0.97)$ observed in our study reinforces the quality and reliability of such imaging method. Despite its advantages, micro-CT cannot be reproduced in an in vivo scenario and, therefore, is not feasible for clinical practice. However, for better understanding of the complexity of the root canals anatomy, micro-CT is the imaging method of choice to assess apical ramifications. In a previous study using micro-CT with $2.5 \mu \mathrm{m}$ scanning resolution, the sizes of ARs of 93 teeth were evaluated. The mean diameter of ARs observed in the anterior teeth, premolars and molars were $79.2 \mu \mathrm{m}, 72.5 \mu \mathrm{m}$, and $53.3 \mu \mathrm{m}$, respectively (22). In the present study, a voxel size of $19.6 \mu \mathrm{m}$ was used and, based on the former study, we believe that it was sufficient to identify the presence of the vast majority of ARs in our sample. Nevertheless, ARs with less than 19.6 $\mu \mathrm{m}$ in diameter, if existent, may not have been detected, constituting a limitation of our research.

Using a clearing technique, De Deus (3) reported a general prevalence of $17.1 \%$ of ARs (considering all dental groups), varying from $0.5 \%$ for mandibular canines to $25.6 \%$ for maxillary molars. The high-resolution images of micro-CT may explain the significantly higher prevalence of ARs in the present study, which showed that 53.3\% of all roots had ARs, ranging from $17.2 \%$ for maxillary incisors to $83.3 \%$ for single-rooted maxillary premolars. Adorno et al. (23) combined clearing technique and digital microscopy to evaluate the prevalence of ARs in maxillary anterior teeth from a Japanese population. Incisors and canines demonstrated a prevalence of $30.7 \%$ and $29 \%$ of ARs, respectively. These results are also not consistent to our study, in which the prevalence of ARs in maxillary incisors and canines were $17.2 \%$ and $65.7 \%$, respectively. Some methodological differences may have contributed to the contrasting results between the studies, such as the different populations assessed and methods of analysis.

Morfis et al. (24) evaluated the apical region of 213 teeth from a Greek population, using scanning electron microscopy. ARs were observed in all dental groups, with a higher prevalence in mandibular premolars $(84,9 \%)$ and maxillary premolars $(75,2 \%)$. These results are consistent with the results of the present study and those of $\mathrm{Xu}$

Table 2. Distribution of apical ramifications in each dental group at $1 \mathrm{~mm}, 2 \mathrm{~mm}$ and $3 \mathrm{~mm}$ from the main foramen

\begin{tabular}{|c|c|c|c|c|c|}
\hline Dental group & $\begin{array}{l}\text { Roots with AR } \\
\text { (1-3 mm) }\end{array}$ & $\begin{array}{l}\text { Number of AR in } \\
1 \mathrm{~mm}(\%) \mathrm{a}^{*}\end{array}$ & $\begin{array}{l}\text { Number of AR } \\
\text { in } 2 \mathrm{~mm}(\%) \mathrm{a}^{*}\end{array}$ & $\begin{array}{l}\text { Number of AR } \\
\text { in } 3 \mathrm{~mm}(\%) b^{*}\end{array}$ & Total of AR $(\%)$ \\
\hline \multicolumn{6}{|l|}{ Maxillary } \\
\hline Incisor & 10 & $14(48.2 \%)$ & $9(31 \%)$ & $6(20.8 \%)$ & $29(100 \%)$ \\
\hline Canine & 23 & $27(42.2 \%)$ & $27(42.2 \%)$ & $10(15.6 \%)$ & $64(100 \%)$ \\
\hline \multicolumn{6}{|l|}{ Premolar } \\
\hline Premolar single-rooted & 45 & $62(46.3 \%)$ & $53(39.5 \%)$ & $19(14.2 \%)$ & $134(100 \%)$ \\
\hline Premolar buccal root & 12 & $15(51.7 \%)$ & $10(34.5 \%)$ & $4(13.8 \%)$ & $29(100 \%)$ \\
\hline Premolar palatine root & 11 & $11(42.3 \%)$ & $14(53.8 \%)$ & $1(3.9 \%)$ & $26(100 \%)$ \\
\hline \multicolumn{6}{|l|}{ Molar } \\
\hline Molar mesiobuccal root & 23 & $32(49.2 \%)$ & $23(35.4 \%)$ & $10(15.4 \%)$ & $65(100 \%)$ \\
\hline Molar distobuccal root & 13 & $17(77.3 \%)$ & $3(13.6 \%)$ & $2(9.1 \%)$ & $22(100 \%)$ \\
\hline Molar palatine root & 13 & $12(46.1 \%)$ & $6(23.1 \%)$ & $8(30.8 \%)$ & $26(100 \%)$ \\
\hline \multicolumn{6}{|l|}{ Mandibular } \\
\hline Incisor & 12 & $10(50 \%)$ & $8(40 \%)$ & $2(10 \%)$ & $20(100 \%)$ \\
\hline Canine & 16 & $20(54 \%)$ & $13(35.2 \%)$ & $4(10.8 \%)$ & $37(100 \%)$ \\
\hline Premolar & 34 & $53(67.1 \%)$ & $23(29.1 \%)$ & $3(3.8 \%)$ & $79(100 \%)$ \\
\hline \multicolumn{6}{|l|}{ Molar } \\
\hline Molar mesial root & 22 & $19(43.2 \%)$ & $20(45.4 \%)$ & $5(11.4 \%)$ & $44(100 \%)$ \\
\hline Molar distal root & 19 & 17 (53.1\%) & $12(37.5 \%)$ & $3(9.4 \%)$ & 32 (100\%) \\
\hline Total & 253 & 309 (50.9\%) & 221 (36.4\%) & 77 (12.7\%) & 607 \\
\hline
\end{tabular}

*Different letters on the number of AR for each millimeter indicate statistically significant difference $(\mathrm{p}<0.05)$. AR=apical ramifications. 
et al. (4), who evaluated teeth of a Chinese population using micro-CT images. They identified ARs in 63.5\% and $71.5 \%$ of the mandibular and maxillary premolars, respectively, while we observed ARs in $62.2 \%$ of the mandibular premolars and $83.3 \%$ of the single-rooted maxillary premolars. The slightly different results between these studies and ours may be attributed to ethnical differences, and possibly to different methods employed for the analysis of the root canals.

Because ARs are difficult to clean and fill, they are commonly associated with persistent intracanal infection and treatment failure $(6,25)$. In this study, several ARs were evaluated using micro-CT images to acknowledge these anatomical complexities and assist endodontists and general dental practitioners in planning and executing procedures with greater predictability of success. For the Brazilian population, most ARs are located in the apical 1 and $2 \mathrm{~mm}$ of the root, with greater prevalence in the posterior teeth and maxillary canines. These findings suggest the need for additional attention in planning endodontic treatment, in addition to strategies to effectively clean the apical region.

\section{Resumo}

O presente estudo utilizou imagens de microtomografia computadorizada (MicroCT) para avaliar a prevalência, número e localização de ramificações apicais (RAs) dos canais radiculares de diferentes grupos dentários em uma população brasileira. Trezentos e sessenta e sete dentes humanos extraídos (totalizando 475 raízes) foram escaneados em um aparelho de MicroCT, com uma resolução espacial de 19,6 $\mu \mathrm{m}$. As imagens foram analisadas em consenso por dois avaliadores, e uma análise descritiva foi realizada para verificar a prevalência, número e localização de RAs em cada grupo dentário. 0 teste Qui-quadrado foi utilizado para comparar a prevalência de RAs em diferentes tipos de raizes e a análise de variância (ANOVA - um critério) comparou o número de RAs em $1 \mathrm{~mm}, 2 \mathrm{~mm}$ e $3 \mathrm{~mm}$ apicais da raiz. 0 nivel de significância foi estabelecido em $5 \%(\alpha=0,05)$. As RAs estavam presentes em 253 (53,3\%) das 475 raizes avaliadas. Foram detectadas 607 RAs com a maioria (530) localizada a 1 e 2 milimetros do forame principal. A mais alta prevalência de RAs foi observada nos caninos superiores (65\%); pré-molares superiores - unirradiculares (83,3\%), raiz vestibular (80\%) e raiz palatina $(73,3 \%)$; pré-molares inferiores $(64,2 \%)$; raiz mésio-vestibular dos molares superiores $(76,6 \%)$; e raiz mesial dos molares inferiores $(66,6 \%)$. Na população brasileira, a maioria dos RAs está localizada em 1 e $2 \mathrm{~mm}$ apicais da raiz, com maior prevalência nos dentes posteriores e nos caninos superiores. Esses achados sugerem atenção adicional ao planejar um tratamento endodôntico, bem como adoção de estratégias para uma limpeza e obturação efetiva da região apical dos dentes.

\section{Acknowledgements}

Supported by grant 2017/05391-9, São Paulo Research Foundation (FAPESP).

\section{References}

1. Ahmed HM, Hashem AA. Accessory roots and root canals in human anterior teeth: a review and clinical considerations. Int Endod J 2016;49:724-736.
2. Vertucci FJ. Root canal morphology and its relationship to endodontic procedures. Endodontic Topics 2005;10:3-29.

3. De Deus QD. Frequency, location, and direction of the lateral, secondary, and accessory canals. J Endod 1975;1:361-366.

4. Xu T, Fan W, Tay FR, Fan B. Micro-computed tomographic evaluation of the prevalence, distribution, and morphologic features of accessory canals in Chinese permanent teeth. J Endod 2019;45:994999.

5. Ricucci D, Siqueira JF Jr. Fate of the tissue in lateral canals and apical ramifications in response to pathologic conditions and treatment procedures. J Endod 2010;36:1-15.

6. Nair PN, Henry S, Cano V, Vera J. Microbial status of apical root canal system of human mandibular first molars with primary apical periodontitis after "one-visit" endodontic treatment. Oral Surg Oral Med Oral Pathol Oral Radiol Endod 2005;99:231-252.

7. Reader CM, Himel VT, Germain LP, Hoen MM. Effect of three obturation techniques on the filling of lateral canals and the main canal. J Endod 1993;19:404-408.

8. De Gregorio C, Estevez R, Cisneros R, Paranjpe A, Cohenca N. Efficacy of different irrigation and activation systems on the penetration of sodium hypochlorite into simulated lateral canals and up to working length: an in vitro study. J Endod 2010;36:1216-1221.

9. Estrela C, Bueno MR, Barletta FB, Guedes OA, Porto OC, Estrela CR, et al. Identification of apical and cervical curvature radius of human molars. Braz Dent J 2015;26:351-356.

10. Estrela C, Rabelo LE, de Souza JB, Alencar AH, Estrela CR, Sousa Neto MD, et al. Frequency of root canal isthmi in human permanent teeth determined by cone-beam computed tomography. J Endod 2015;41:1535-1539.

11. Ordinola-Zapata $\mathrm{R}$, Bramante $\mathrm{CM}$, Villas-Boas $\mathrm{MH}$, Cavenago $\mathrm{BC}$, Duarte $\mathrm{MH}$, Versiani MA. Morphologic micro-computed tomography analysis of mandibular premolars with three root canals. J Endod 2013;39:1130-1135.

12. Paes da Silva Ramos Fernandes $L M$, Rice $D$, Ordinola-Zapata $R$, Alvares Capelozza AL, Bramante CM, Jaramillo D, et al. Detection of various anatomic patterns of root canals in mandibular incisors using digital periapical radiography, 3 cone-beam computed tomographic scanners, and micro-computed tomographic imaging. J Endod 2014;40:42-45.

13. Bucchi C, Gimeno-Sandig A, Manzanares-Céspedes, C. Enlargement of the apical foramen of mature teeth by instrumentation and apicoectomy. A study of effectiveness and the formation of dentinal cracks. Acta Odontol Scand 2017;75:488-495.

14. De Souza Filho FJ, Benatti O, de Almeida OP. Influence of the enlargement of the apical foramen in periapical repair of contaminated teeth of dog. Oral Surg Oral Med Oral Pathol 1987;64:480-484.

15. Ricucci D, Siqueira Jr JF. Recurrent apical periodontitis and late endodontic treatment failure related to coronal leakage: a case report. J Endod 2011;37:1171-1175.

16. Vera J, Siqueira JF, Ricucci D, Loghin S, Fernández N, Flores B, et al. One- versus two-visit endodontic treatment of teeth with apical periodontitis: a histobacteriologic study. J Endod 2012;38:10401052.

17. Ricucci D. Apical limit of root canal instrumentation and obturation, part 1. Literature review. Int Endod J 1998;31:384-393.

18. Ricucci $D$, Russo J, Rutberg $M$, Burleson JA, Spångberg LS. A prospective cohort study of endodontic treatments of 1,369 root canals: results after 5 years. Oral Surg Oral Med Oral Pathol Oral Radiol Endod 2011;112:825-842.

19. Gao X, Tay FR, Gutmann JL, Fan W, Xu T, Fan B. Micro-CT evaluation of apical delta morphologies in human teeth. Sci Rep 2016;1-6.

20. Kim $Y$, Perinpanayagam $H$, Lee JK, Yoo YJ, Oh $S, G u$, et al. Comparison of mandibular first molar mesial root canal morphology using micro-computed tomography and clearing technique. Acta Odontol Scand 2015;73:427- 432.

21. Ordinola-Zapata $R$, Bramante CM, Versiani MA, Moldauer BI, Topham G, Gutmann JL, et al. Comparative accuracy of the clearing technique, CBCT and micro-CT methods in studying the mesial 
root canal configuration of mandibular first molars. Int Endod J 2016;50:90-96.

22. Xu T, Tay FR, Gutmann JL, Fan B, Fan W, Huang Z, et al. Micro computed tomography assessment of apical accessory canal morphologies. J Endod 2016;42:798-802.

23. Adorno CG, Yoshioka $T$, Suda $H$. Incidence of accessory canals in Japanese anterior maxillary teeth following root canal filling ex vivo. Int Endod J 2010;43:370-376.

24. Morfis A, Sylaras SN, Georgopoulou M, Kernani M, Prountzos F. Study of the apices of human permanent teeth with the use of a scanning electron microscope. Oral Surg Oral Med Oral Pathol 1994;77:172176.

25. Ricucci D, Siqueira JF Jr. Biofilms and apical periodontitis: study of prevalence and association with clinical and histopathologic findings. J Endod 2010;36:1277-1288.

Received May 12, 2020

Accepted July 20, 2020 